\title{
PASSADO E PRESENTE: SICÍLIA E MILETO, ROMA E AFRODÍSIAS NO ROMANCE DE CÁRITON ${ }^{1}$
}

\begin{abstract}
Adriane Silva Duarte*
RESUMO: Quéreas e Calírroe, romance de Cáriton de Afrodísias (I d.C.), tem como ponto de partida e de retorno do par protagonista a cidade de Siracusa, na Sicília do início do século IV a.C. Uma parte considerável da ação, contudo, se passa em Mileto, para onde se desloca a heroína. Procura-se investigar aqui as razões dessa opção de Cáriton, que já na primeira sentença de sua obra proclama sua nacionalidade, alertando o leitor que o autor é um grego que vive na periferia do império romano. A hipótese é que a escolha por situar a ação do romance no passado reflita menos a emulação do relato historiográfico, especialmente o de Tucídides, mas antes uma estratégia para tratar indiretamente da relação entre Afrodísias e Roma no presente.
\end{abstract}

PALAVRAS-CHAVE: romance antigo; Cáriton; Quéreas e Calírroe; Afrodísias; Roma.

$$
\begin{array}{r}
\text { PAST AND PRESENT: SICILY AND MILETUS, } \\
\text { ROME AND APHRODISIAS IN CHARITON'S NOVEL }
\end{array}
$$

\begin{abstract}
In Chariton's Chaereas and Callirhoe (I AD), the protagonist pair starts at and returns to the city of Syracuse, Sicily, in the early fourth century BC. A considerable part of the action, however, takes place in Miletus, to where the heroine has gone. This paper's aim is to investigate the reasons of Chariton's option, he who already at the very first sentence his work proclaims his nationality, warning the reader that the author is a Greek, living in the outskirts of the Roman Empire, in the city of Aphrodisias. My hypothesis is that the choice of placing the novel's plot in the past and the prominence attributed to Sicily suggest a strategy to address indirectly the links between Aphrodisias and Rome in his present time, rather than an emulation of historiographical accounts, especially that of Thucydides.
\end{abstract}

KEYWORDS: Ancient novel; Chariton; Chaereas and Callirhoe; Aphrodisias; Rome.

\footnotetext{
${ }^{1}$ Uma versão preliminar desse texto foi apresentada durante o XX Congresso da Sociedade Brasileira de Estudos Clássicos: Público e Privado na Antiguidade, novembro de 2015, Mariana-MG.
}

* Departamento de Letras Clássicas e Vernáculas, Universidade de São Paulo. 
trama de Quéreas e Calírroe, romance de Cáriton de Afrodísias (I d.C.), passa-se no
começo do século IV a.C. e tem como ponto de partida e de retorno do par
protagonista a cidade de Siracusa, na Sić́lia, após o périplo a que foi destinado por Afrodite. Uma parte considerável da ação, contudo, acontece em Mileto, para onde se desloca a heroína. Nesse texto busca-se investigar as razões dessa opção de Cáriton, que já na primeira sentença de sua obra proclama-se natural de Afrodísias, na Cária, alertando o leitor que o narrador assume a identidade de um grego que vive na periferia do império romano. ${ }^{2}$

Há dois aspectos a se ressaltar aqui. O primeiro reside no distanciamento temporal que Cáriton cria entre o narrador e o narrado. Esse se debruça sobre o passado. Apenas o fato de Cáriton ter situado sua narrativa amorosa em um dado período de tempo e, mais que isso, ter se preocupado em dotá-la de marcos temporais precisos, merece destaque. Três de seus personagens são figuras históricas: Hermócrates, o pai da heroína, é um destacado comandante da frota siciliana durante a invasão ateniense, como atesta Tucídides (IV.58-65; VI.32-5, 72-3; VII.21, 73; VIII.26-9, 45, 85); Artaxerxes, o rei persa, remete a Artaxerxes II Mnemon, cujo reinado vai de 404-358 a.C.; Estatira é esposa de Artaxerxes II. ${ }^{3}$ Além disso, apesar dos anacronismos e inconsistências (a maior reside no fato de Hermócrates ter morrido em 407, antes, portanto, de Artaxerxes subir ao trono), é visível que ele busca conferir verossimilhança histórica às situações que cria. Isso é particularmente notável porque uma das marcas do "tempo de aventuras", que, segundo Bakhtin, é característico dos romances antigos, é a ausência da localização histórica. Assim, segundo ele (Bakhtin, 1988, p. 217):

Em todo o mundo do romance grego, com todos os seus países e cidades, construções, obras de arte, estão totalmente ausentes quaisquer indícios do tempo histórico, quaisquer vestígios de época.

Ao revisitar a questão recentemente, E. Bowie (2006, p. 19) parece dar razão ao estudioso russo. Ele nota que, à parte Cáriton e Heliodoro (que também situa sua história no período clássico), os demais romancistas colocam seus personagens em uma época suficientemente neutra, para que leitor contemporâneo facilmente pudesse reconhecê-la como sua, mas bastante desprovida de detalhes para que a trama pudesse prescindir do contexto histórico, o que lhe confere uma certa aura atemporal. Para ele, os autores promovem uma

\footnotetext{
${ }^{2}$ Eis a sentença de abertura do romance (Quéreas e Calírroe, I. 1): "Eu, Cáriton de Afrodísias, secretário do orador Atenágoras, passo a narrar uma história de amor que aconteceu em Siracusa"

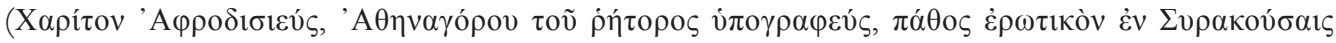

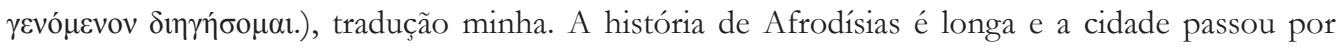
várias "refundações" que implicaram ao menos três mudanças de nome (VI a.C a VII d.C.), mas nesse contexto é significativo anotar que foi apenas a partir do reinado de Augusto que passou a ser designada oficialmente (em moedas e inscrições) por esta designação apenas. Para o histórico de Afrodísias, remeto a Chaniotis (2003, p. 70).

${ }^{3}$ Para o exame mais detalhado dos usos que Cáriton faz de elementos históricos, remeto ao artigo de Hunter (1994).
} 
deliberada fusão entre o mundo helenístico e o romano. De qualquer forma, parece evidente que eles não estavam particularmente ávidos em dotar suas obras com elementos de realidade histórica.

Em segundo lugar, vale notar que, espacialmente, o cenário proposto pelo romancista também se distancia daquele em que manifestamente o narrador se coloca na oração com que abre seu livro. Tanto a Sicília quanto Mileto, ou ainda Babilônia e Atenas, cidades de referência em Quéreas e Calírroe, não guardam especial relação com a Afrodísias natal de Cáriton, sem sombra de dúvida mais próxima de Roma e de outras "potências" regionais, como Éfeso, por exemplo. ${ }^{4}$ Obviamente, o recorte temporal proposto é determinante para a ausência tanto de Afrodísias quanto de Roma, uma vez que, no início do séc. IV a.C., uma não existia enquanto tal e a outra ainda era irrelevante no cenário geopolítico.

Então, a primeira pergunta que surge é por qual razão Cáriton decide situar sua história no passado. A relevância de Hermócrates e as constantes referências à derrota sofrida pelos atenienses no curso da expedição à Sicília, somadas a outras marcas, sobretudo de léxico e estilo, apontam a narrativa historiográfica e, particularmente, Tucídides, como uma fonte de inspiração para o romancista. ${ }^{5}$ Assim, Cáriton teria optado por situar o seu páthos erōtikén no passado, no intuito de emular o registro da história ainda que para compor "fábulas" (registro da ficção), ou de conferir verossimilhança a sua matéria, ao introduzi-la à maneira dos relatos historiográficos e ao mesclar personagens que de fato existiram aos "ficcionais" - a existência de um Hermócrates de Siracusa, atestada em Tucídides, por exemplo, confere maior verossimilhança à personagem de Calírroe, sua filha.

Ainda assim, a escolha de Cáriton suscita outras questões. Como o recorte temporal acarreta a necessária elisão de Roma e Afrodísias, o que significam essas ausências? E do ponto de vista da delimitação espacial, caberia perguntar: por que a Sicília, por que Mileto?

Antes de tentar dar alguma resposta, interessa estabelecer a relação que o romance, nesse caso Quéreas e Calírroe, mantém com o seu contexto imediato de produção. Defendo que a história de Calírroe está enraizada em Afrodísias e não poderia ter surgido em nenhuma outra parte e em nenhuma outra época. E. Bowie (2002, p. 62), na discussão que faz da cronologia dos primeiros romances gregos, arrisca o palpite de que o fato de Eros ter se tornado o centro desse gênero novo não é explicável apenas pelas mudanças gerais das condições sociais e políticas, mas que elementos locais teriam tido aí papel decisivo. Foi no decorrer do séc. I d.C., diz ele, "na próspera cidade de Afrodísias, sede de um culto importante de Afrodite", que "um escritor ou mais escritores desenvolveram uma fórmula de sucesso", o páthos erōtikón, que logo se disseminou pelo mundo habitado.

E é realmente impressionante a concentração dos romances mais antigos que conhecemos na segunda parte do século I e nas cercanias de Afrodísias. Como nota Bowie (2002, p. 57-8, tradução minha):

\footnotetext{
${ }^{4}$ Para relação com Roma e outras potências regionais, cf. especialmente Edwards (1994), mas também Badian (1984), de Chaisemartin (1997), Chaniotis (2003).

${ }^{5}$ Para a dívida de Cáriton com a historiografia, consultar Hunter (1994, p. 1058-64 e 1067-9) e Brandão (2005, p. 110-8).
} 
O que realmente se deve reter dessa discussão acerca [da cronologia] dos primeiros romances? É provável que todos tenham sido compostos no intervalo de poucas décadas: Cáriton entre 41 e 62, Nino entre 63 e 75, Xenofonte depois de 65 d.C, Metioco e Parténope, datável com menos segurança, mas devido a sua proximidade estilística com Cáriton, pertencente ao mesmo período. Esse contexto pode ser circunscrito geograficamente: Cáriton e o autor de Nino, ambos trabalhando em Afrodísias, Xenofonte (se de fato ele é de Éfeso), a 150 quilômetros de distância, em uma cidade que tinha fortes vínculos com Afrodísias. Talvez não seja acaso que o cenário de algumas cenas importantes de Metíoco e Parténope seja Samos, que é, dentre as principais ilhas do Egeu, a mais próxima de Éfeso e Afrodísias. ${ }^{6}$

Para ele, a equação tempo e espaço é crucial para a configuração que a prosa grega de ficção veio a adquirir, indicando que o romance é fruto do domínio político romano sobre as cidades gregas, que estão na periferia do império e orbitam em torno de Roma, ao mesmo tempo que lutam para assumir a liderança regional, e que, de certa forma, elabora uma resposta a esse estado de coisas. $\mathrm{O}$ romance se torna um gênero popular porque a região que o vê nascer provê um caldo cultural rico e variado, que favorece o trânsito de pessoas e ideias e torna quase que instantânea a disseminação dessa produção de Roma a Alexandria. E é isso, ao meu ver, que não se deve perder de vista ao estudar a obra de Cáriton. ${ }^{7}$

Em vista disso, retomo uma provocação feita por J. L. Brandão (2014, p. 94), para quem não é apropriado falar em romance "grego" antigo, uma vez que "não há mais, sob Roma, autores gregos, mas todos são romanos, independentemente da língua em que escrevem”. De modo que, remetendo a suas próprias palavras (Brandão, 2014, p. 93), podese concluir que:

[...] falar de exemplares gregos e latinos, ou mesmo greco-latinos, tomando como referência a língua em que os textos são escritos, esmaece que se trata de uma produção romana, no sentido de que só surge no Império de Roma e deve responder a uma expectativa própria dessa situação.

Nesse cenário, cabe, então, questionar a tal "expectativa própria dessa situação". Qual seria ela? Uma característica notável desse corpus que se convencionou denominar de romances de amor e aventura, que abrange textos escritos em grego, entre os séculos I e IV d.C., é que, apesar de seus autores se inserirem num mundo em que Roma é o centro político

\footnotetext{
${ }^{6}$ De Nino e Metioco e Parténope tem-se apenas fragmentos, que podem ser lidos na coletânea organizada por Reardon (2008 [1989]).

${ }^{7} \mathrm{Um}$ dado importante sobre o sucesso instantâneo do gênero está no fato de que Petrônio, que fora governador da Bitínia, na Ásia Menor, compõe o Satíricon na segunda metade do século I d.C., como uma paródia dos romances gregos à moda de Cáriton e Xenofonte.
} 
e de tematizarem a viagem por vastas extensões de terra e mar, tal cidade não é destino, nem escala, e sequer é referida por eles. A ausência de Roma foi entendida por alguns estudiosos do romance como significativa, na medida em que sinalizaria a clara disposição das elites gregas das cidades à margem do Império de afirmarem uma identidade própria, baseada na "grecidade" e cuja permanência seria percebida como fruto dos casamentos entre pares celebrados nos enredos. Haveria, portanto, um movimento deliberado dessas elites de evasão ou negação de Roma, ao menos na esfera da ficção. Esse movimento teria sua contrapartida na eleição das intrigas amorosas como tema principal, fazendo com que a vida privada, o que é da ordem do doméstico, predominasse sobre a esfera pública. ${ }^{8}$

No caso de Cáriton, essa "fuga" do contexto imperial ficaria ainda mais evidente pela decisão de situar a trama do romance no início do século IV a.C, no pós-Guerra do Peloponeso, focando, portanto, no período senão áureo, mas ainda prestigioso do passado grego, em que as cidade-estado pontificavam e o ideal grego de paideía era reconhecido de leste a oeste, ou seja, de Mileto a Siracusa. Retroceder a tal época traria a nostalgia de um tempo em que a Grécia ainda era a referência maior.

Essa interpretação é problemática, na medida em que, à época de Cáriton, os vínculos entre Afrodísias e Roma são fortes, havendo evidências abundantes do interesse da cidade cária em preservá-los e estreitá-los. Assim, é difícil, compartilhando da leitura acima, tratar o romance como uma literatura "escapista". Acredito que, no caso de Cáriton, a aliança que Afrodísias mantinha com Roma, sedimentada ao longo das campanhas militares contra Mitrídates do Ponto, no século I a.C. e no culto comum a Afrodite, que começa a ganhar importância em Roma no mesmo período, consolidando-se com a ascensão de César e Otávio, que se querem descendentes da deusa pela via de Eneias e Iulo, gerasse uma expectativa diversa.

Afrodísias passa a ter relevância geopolítica quando, no contexto das guerras Mitridáticas (88-84; 83-81;75-63 a.C.), se alia a Roma para rechaçar as pretensões de Mitrídates VI do Ponto (120-63 a.C.), que ameaçavam os interesses romanos na Ásia Menor. O apoio dado às legiões romanas comandadas por Sula (Lucius Cornelius Sulla Felix, 138-73 a.C.) foi decisivo para colocar a cidade na mira de Roma. Desde o início, Afrodite e seu culto desempenharam papel importante nessa aliança política para ambos os lados, como atesta a oferenda feita por Sula à deusa de Afrodísias, em que lhe atribui traços marciais. Apiano, em Guerras Civis (BC I.11.97), traz o testemunho disso (tradução minha):

Uma vez foi lhe dado um oráculo que fazia previsões sobre seu futuro:

'Creia em mim, Romano! Cípris deu grande poder

e vela pela raça de Eneias. Você deve fazer a todos os imortais oferendas anuais. Não esqueça disto: trazer presentes a Delfos. Mas há um lugar onde

\footnotetext{
${ }^{8}$ Para uma síntese da questão, Stephens (2008), também Schwartz (2003).
} 
o Tauros nevado se eleva, ${ }^{9}$ onde fica a cidade

elevada dos Cários, que, ao habitá-la, fizeram-na epônima de Afrodite.

Toma um machado de lâmina dupla e oferta a ela. Poder ilimitado será o seu!'

[...]E Sula enviou uma coroa de ouro e o machado, com a seguinte inscrição:

'O ditador Sula ofertou à Afrodite,

por tê-la visto em um sonho à frente de seu exército,

combatendo com as armas de Ares. ${ }^{10}$

Oráculo, oferenda e sonho devem ser vistos como parte da estratégia de Sula para conquistar aliados entre os gregos do continente e da Ásia e, ao mesmo tempo, buscar prestígio entre a elite romana, uma vez que membros de importantes famílias, a gens Iulia e a gens Memmia, propagandeavam sua ligação com a estirpe de Eneias, impulsionando a popularidade da deusa e da lenda troiana em Roma - exemplo disso está na adoção do culto de Vênus de Érice (Sicília) em Roma. ${ }^{11}$

Se relevante para Roma, para Afrodísias, a aliança era essencial e, nesse quadro, não é demais afirmar que o afrodisiense se queria antes romano do que grego, ou, em outros termos, era determinante para sua identidade a relação com o centro do poder e, em breve, do Império. A necessidade de afirmar e perpetuar essa relação estratégica se manifesta de várias maneiras, sendo, à época de Cáriton, o complexo do Sebasteion a mais eloquente. O que representa a construção desse edifício em que se celebra Roma e suas conquistas para a cidade está bem-posto na síntese que B. C. Ewald (2014) faz da tese de R. R. R. Smith, em livro recém-publicado sobre os relevos de mármore do Sebasteion (tradução minha):

\footnotetext{
${ }^{9}$ Essa menção a Tauros nevado é obscura. Para Robert, o texto estaria corrompido e a leitura correta seria Stauros (Cruz), alusão ao futuro nome da cidade Staurópolis. Como essa designação é tardia (V d.C.), parece duvidoso que assim o seja. Outros pensam ter havido confusão com outra cidade de mesmo nome, na Cilícia. Cf. Robert (1966) e Brody (2001, p. 106).

${ }^{10}$ Cf. Appian, BC, I.11.97:

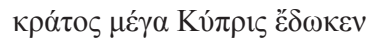

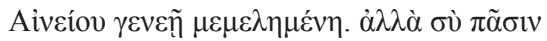

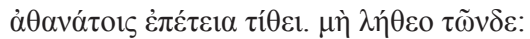

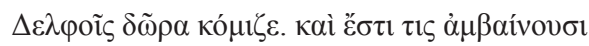

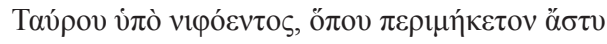

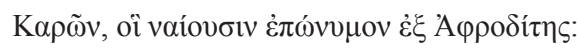

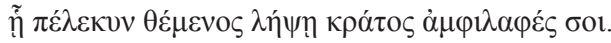

$[\ldots]$

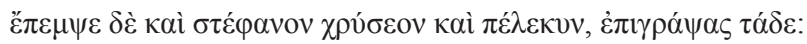

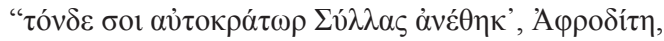

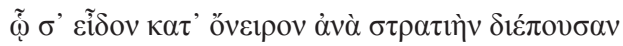

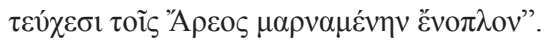

${ }^{11}$ Cf. de Chaisemartin (1997, p. 40-1).
} 
O planejamento e construção do complexo do Sebasteion pode ser datada com alguma certeza do intervalo que vai do início do reinado de Tibério (14-37) ao de Nero (54-68), com grande parte da obra executada no período de Claudio (41-54) e durante os primeiros anos do de Nero. Smith imagina de forma plausível dois fatores-chave por trás da concepção do complexo no início do período de Tibério: 1) uma aguda 'ansiedade' da parte da cidade que tinha capitalizado com sucesso sua associação com Vênus/Afrodite e que tinha sido tratada com privilégios por César e Augusto, mas cujo futuro era menos certo depois da morte desse; e 2) a renovação de seus privilégios em 22 d.C., quando, em um espetáculo digno de memória registrado por Tácito (Anais 3.60-63), o Senado romano revisou os direitos de asilo das póleis gregas depois do relato de violações. Qualquer que fosse o caso, o edifício do Sebasteion teria sido a expressão de gratidão pelos privilégios e favores concedidos pelos romanos no passado e a 'garantia' da sua renovação no futuro. Não deve causar surpresa, então, que o mito e a história romana apareçam nos relevos do Sebasteion de forma merecida (o que não é usual no leste grego), que eles tragam personificações do Senado e do Povo romanos, e que haja paralelos estruturais entre a linguagem visual dos relevos e o elogio dos imperadores (e, poder-se-ia acrescentar, de deuses e cidades) na retórica epidítica.

Assim como esse movimento de assimilação ao mundo romano se evidencia na arquitetura da cidade, é de se supor que também se manifestasse na literatura. Sugiro que, ao compor Quéreas e Calírroe, Cáriton quis erigir um monumento que cumprisse a mesma função do Sebasteion, mas com palavras em lugar de pedras. Resta examinar como ele o fez, já que, como coloca C. Connors (2002, p. 15, tradução minha), "só porque o romance de Cáriton não menciona Roma isso não significa que ele não seja sobre Roma ou, ao menos, uma resposta a ela".

Seria agora o momento de voltar àquelas questões iniciais: por que a Sicília e Mileto como cenários do romance? O que essa escolha diz a respeito do contexto de produção do romance? Outros estudiosos já se colocaram a mesma questão, de modo a valer fazer aqui uma breve síntese de suas respostas:

a) A opção pela Sicília no momento que se sucede de imediato a Guerra do Peloponeso visa a enfatizar o declínio de Atenas como potência políticomilitar. Connors (2002, p. 16) observa que a escolha de Siracusa como cenário inicial e final do romance e pátria dos protagonistas ressalta o fim da aspiração imperialista de Atenas. Em suas palavras: "Siracusa, então, não é apenas uma cidade grega qualquer, mas um lugar com histórias imperiais a contar, histórias de um império dando lugar a outro". Na mesma linha, Whitmarsh (2011, p. 56, tradução minha) observa que fazer da Sićlia "o centro do mundo implica descentrar o continente grego, deslocando-o em direção ao leste 
bárbaro - uma construção simbólica que reflete mais o mapa italocêntrico da Roma imperial do que as ideias gregas tradicionais". Eu acrescentaria: sinalizar o ocaso de Atenas é uma forma de reivindicar sua herança cultural. Posto vacante, Afrodísias se candidata com seu novo conjunto arquitetônico e o gênero literário que está contribuindo para criar. Ou seja, a cidade quer para si a glória que foi a de Atenas, mas no novo mapa do império, em que Roma é o epicentro.

b) Ainda Connors (2002, p. 19) sugere que Siracusa desempenha papel importante na luta pelo poder que opõe Otávio e Sexto Pompeu (39-36 a.C.). Esse, assumindo o controle das águas sicilianas, trata de impedir a passagem de grãos para Roma até ser derrotado por Agripa em 36 a.C., fato que abre caminho para que Otávio se firme como único regente. Na retórica de Otávio, a estratégia do rival é equiparada a um ato de pirataria. Diz Connors (2002, p. 19): “ $\mathrm{Na}$ sequência do conflito entre Otávio e Sexto Pompeu, Siracusa assume outro significado: para Augusto, assim como para Cáriton, Siracusa é um lugar onde se resolve um problema de pirataria e se inicia um império". Assim, quando Cáriton cria uma história em que a heroína é raptada por piratas em Siracusa, cuja captura e punição operam como reafirmação do poder local, haveria uma referência à ascensão de Augusto, que patrocinou uma grande reurbanização na cidade após sua vitória: "Como o fechamento dos portões do templo de Janus em Roma em 29, as reformas contemporâneas de muralhas e edifícios em Siracusa [por iniciativa de Augusto] são um marco do fim da Guerra Civil" (Connors, 2002, p. 20). Ou seja, o castigo de Téron, o pirata em Quéreas $e$ Calírroe, que fortalece a autoridade de Hermócrates, líder inconteste em Siracusa, remete à derrota de Pompeu e à consolidação do poder de Augusto.

c) Mileto, por sua vez, foi identificada por vários estudiosos como um substituto adequado para Afrodísias tanto por sua proximidade quanto por ter sediado um culto importante a Afrodite - note-se que Cáriton dota "sua Mileto" de templos e festas dedicadas à deusa patrona de sua cidade natal. ${ }^{12}$ Assim, na representação de Dionísio, o mais destacado cidadão de Mileto, como um exemplar bem-acabado do homem grego educado, Cáriton projetaria a elite afrodisiense.

d) Trzaskoma (2012, p. 301) sugere que por trás da escolha de Mileto estivesse "o jogo intertextual entre Quéreas e Calírroe e a Anábase, de Xenofonte, refletindo o papel político desempenhado pela cidade na disputa entre Ciro, o jovem e Artaxexes II - graças à influência do sátrapa cário Tissafernes, a cidade se posta ao lado de Artaxerxes, quando da revolta liderada por seu irmão. Para além da intertextualidade, na minha leitura, evocar esse contexto teria por fim

${ }^{12}$ Tilg (2010, p. 32-6), Whitmarsh (2011, p. 52-3) e Trzaskoma (2012, p. 300) fazem um breve balanço bibliográfico da questão. 
remeter ao evento fundador da Afrodísias moderna, sua aliança com Roma diante das forças rebeldes de Mitrídates do Ponto, em que a cidade apoia as forças romanas contra a tentativa de rebelião.

e) Tilg (2010, p. 32-6) sugere ainda a possibilidade de que Os relatos milésios, de Aristides (cerca de I a.C.), textos de teor erótico escritos em prosa, tenham tido influência na escolha de Cáriton por inspirarem a formação do novo gênero.

Essas são apenas algumas das respostas da crítica às nossas questões iniciais. Noto que, em sua maioria, poderiam ser combinadas, pois não são excludentes. Creio, contudo, que se pode acrescentar ainda outras.

Não passou despercebido aos estudiosos que Quéreas e Calírroe guarda certos paralelos com a Eneida. ${ }^{13}$ Para além dos ecos e paralelismos temáticos, um aspecto me chama a atenção em especial, a estratégia de Virgílio de celebrar Roma e as conquistas de Augusto através da lenda heroica, situando sua narrativa no passado mítico, no momento em que se produziram as condições que propiciariam a futura fundação da cidade. Penso que, se Cáriton planejasse emular a Eneida, teria também optado por situar no passado sua narrativa, que teria por tema a fundação de uma nova civilização. O filho de Calírroe e Quéreas, deixado aos cuidados do "milésio" Dionísio, seria a semente dessa lenda fundadora, em que a herança grega é transladada do ocidente para o oriente, ou seja, da Sicília para Mileto.

Outro recurso virgiliano, esse inspirado por Homero, a abertura in medias res, resulta que o poema tem início na travessia da frota capitaneada por Eneias da Sicília para Cartago. Ou seja, no começo da Eneida, o herói parte da Sicília, não de Troia. Em consonância com a lenda troiana, Sicília guarda forte conexão com a deusa cultuada em Afrodísias - o Santuário de Érice, cuja fundação é atribuída a Eneias e é centro de peregrinação para os romanos -, e, no poema de Virgílio, é abrigo de florescente colônia troiana e acolhe os restos mortais de Anquises. Ou seja, a Sicília é um bom ponto de partida, tanto para dar destaque às conexões de Afrodísias com a herança grega quanto à aliança com Roma, fundada, entre outras coisas, no culto a Afrodite. ${ }^{14}$

Assim como na Eneida, Vênus vela pela segurança de seu filho, procurando-lhe garantir as glórias imorredouras e mantendo-o a salvo das armadilhas de Juno, em Quéreas e Calírroe, Afrodite conduz a heroína da Sicília a Mileto, e mesmo além (Babilônia/Pérsia, Arados/Fenícia-Síria), e, contrapondo-se aos planos de Fortuna/Týche, a divindade adversa, garante sua reunião com Quéreas e o retorno à Sicília, mas sem o filho, que fica aos cuidados do pai putativo. ${ }^{15}$

\footnotetext{
${ }^{13}$ Para a influência de Virgílio sobre Cáriton, cf. Tilg (2010, p. 271-91).

${ }^{14}$ Cf. Eneida I. 34 ("Mal a Sicília perderam de vista...”); V. 23-31 (quando após deixar Cartago, Eneias aporta na Sicília, em Érix, e busca refúgio na colônia fundada por Acestes, onde está sepultado seu pai); V. 755-61 (Eneias funda nova colônia troiana e o templo de Vênus em Érice).

${ }^{15}$ O protagonismo de Eros e Afrodite no romance de Cáriton é claro. Eros decidiu "formar a parelha"

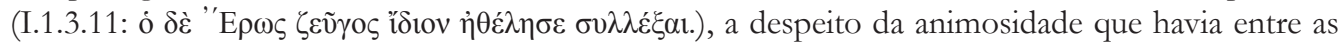
famílias de Quéreas e Calírroe e planejou para que os jovens se encontrassem e se apaixonassem
} 
Parece haver aí a história de um herói fundador, e de fato o filho da heroína será comparado a "Zeto, Anfion e Ciro" (QぬC, II.9). Embora os pais biológicos contem com seu regresso, quando atingida a idade adulta, para ombrear as proezas de Hermócrates, seu avô, essa criança sem nome está fadada a viver entre dois mundos, fundando talvez uma dinastia que resulte em Afrodísias - Eneias vai de leste a oeste fundando uma colônia em Érice, seus descendentes "sicilianos" fazem o trajeto inverso, deixando em Mileto um descendente para repovoar a Ásia Menor.

É verdade que o texto de Cáriton não traz nada disso de forma explícita. Mas esse mito fundador explicaria outra característica ímpar do romance de Cáriton: é o único romance do corpus, em que as heroínas se destacam pela castidade, a trazer uma protagonista marcada pela bigamia e maternidade. É certo que haveria de se tomar certos cuidados para não sugerir soberba de a província querer equiparar-se à Roma: assim, o herói fundador, nesse caso, não deveria ser filho da deusa, como Eneias, mas filho de uma mortal, favorita da deusa - os heróis do romance não pertencem mais à esfera do mito, mas se movem em terreno humano.

Se Calírroe é uma enviada da Afrodite de Érice, o que dizer de Quéreas, o pai da criança predestinada? Condenado durante boa parte da trama à impotência, subordinado à autoridade de Hermócrates, inferiorizado diante do prestígio de Dionísio e do poder do Rei Persa, é na guerra que o herói prova o seu valor. Parece-me significativo que, no momento em que ele experimenta sua aristeía no livro VII, impondo grande revés a Artaxerxes, cuja frota derrota, o que resulta na captura de Arados, ilha síria que abrigava os tesouros do rei, inclusive a rainha e Calírroe, o herói refira-se a si próprio como epaphróditos. Vale examinar a passagem. Alertado por um de seus auxiliares de que dentre os prisioneiros encontra-se uma mulher de extraordinária beleza - que os leitores sabem ser Calírroe, mas cuja identidade ele ignora -, que se recusa a comparecer diante dele, mesmo sob promessa de um pretenso casamento, ele desabafa (Q\&广C, VII 6.12, tradução minha):

"Sou mesmo o favorito de Afrodite e dono de um charme irresistível
(epaphróditos kaì erásmios), se ela, até antes de me ver, me dá as costas
e me cumula de ódio! Parece que o coração dessa mulher não é
desprovido de nobreza. Não se deve forçá-la a nada, mas deixem
ficar como escolher. É do meu feitio honrar a castidade. Talvez ela
também guarde luto por seu marido".

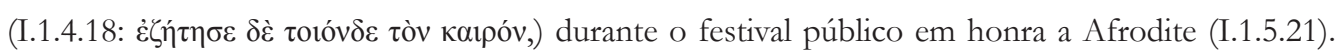
A deusa favorece a união, cedendo às preces de Calírroe, mas depois, irritada com os ciúmes despropositados de Quéreas, patrocina a separação do casal e o novo casamento da jovem com Dionísio, em Mileto. Por fim, serenados os ânimos, a deusa propicia a reunião do par amoroso (VIII 1.3: "Como desde o princípio uniu sob o jugo a parelha mais bela, após estafá-los por terra e mar, novamente quis devolvê-los aos braços um do outro”, tradução minha). 
Embora a menção se dê no contexto erótico, e não no militar, julgo haver aí uma referência a Sula, que adotou a alcunha, como atestam as seguintes passagens de Plutarco (Vida de Sula, 34.4, tradução minha) e Apiano (Guerras Civis, I.11.97) ${ }^{16}$ :

Mas ele mesmo (i. e., Sula), em correspondência e tratativas com os gregos, designa-se Epaphróditos e o nome inscrito em nossos troféus é Lucio Cornélio Sula Epaphróditos.

Encontrei um documento que relata que Sula recebeu o título de Epaphróditos por um decreto do Senado, o que não me parece sem propósito, já que ele também era chamado Faustus, e esse nome parece ter o mesmo significado que epaphróditos. ${ }^{17}$

Santangelo (2007, p. 213) considera que a adoção do nome fez parte da estratégia de Sula para predispor as elites gregas, tanto no continente quanto na Ásia Menor, favoravelmente aos romanos no contexto imediatamente posterior às Guerras Mitridáticas (tradução minha):

O principal objetivo de Sula era retomar o controle na Grécia Oriental, ao mesmo tempo compelindo as elites locais a se aproximarem de Roma e a retomarem a cooperação com ela. Para fazer isso, ele não se limitou a pressioná-las com demandas excessivas, que deixaram as cidades da Ásia Menor sem outra escolha que a de buscar patronos romanos. Ele também tentou convencer os gregos de que, de alguma forma, eles partilhavam uma herança comum com os romanos. Os romanos eram descendentes da filha de Zeus, a deusa que preside sobre o amor e o convívio social. Eles também descendiam dos troianos, que enfrentaram os gregos, mas que eram desde muito considerados bem assemelhados a eles. O potencial dessa identidade ambígua era óbvio. Roma era, de algum modo, parte do mundo grego e, ao mesmo tempo, irremediavelmente diferente dele.

Se essa retórica tinha um apelo amplo, ecoou ainda mais forte em Afrodísias, alvo manifesto da atenção do ditador romano, que a elegeu como aliada de Roma em vista do simbolismo de seu nome e da importância do culto de Afrodite ali. Sula torna-se a um só tempo o inventor de Afrodísias para os romanos e o principal avalista dos interesses de suas elites. Assim, não creio ser despropositado propor que, à maneira celebratória do Sebasteion,

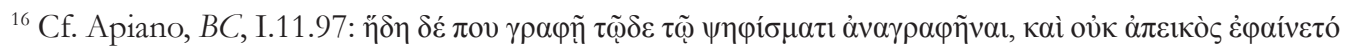

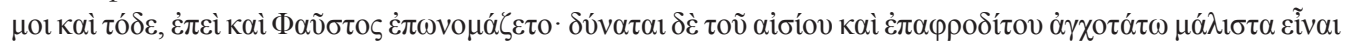

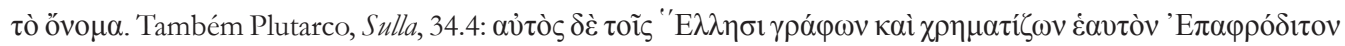

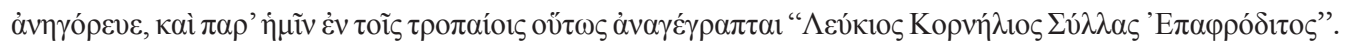
${ }^{17}$ Sobre essa ilação de Apiano e as relações entre Fausto, Felix e Epaphróditos, cf. Santangelo (2007, p. 210-1).
} 
Cáriton tenha conferido a Quéreas traços de Sula como forma de lembrar a origem das relações entre Roma e Afrodísias.

Dois outros elementos do romance parecem sinalizar nesse sentido. Em primeiro lugar, a tão propagada derrota de Atenas pela frota siciliana de Hermócrates pode ser lida à luz da bem-sucedida campanha de Sula contra a cidade que, no âmbito das Guerras Mitridáticas (87 a.C.), levou a sua captura e subsequente deposição do tirano Ariston, aliado de Mitrídates. O episódio veio a resultar na submissão de Atenas a Roma. Em segundo lugar, a vitória do epaphróditos Quéreas contra o rei Persa pode evocar o sucesso militar romano nas Guerras Mitridáticas. Não cabe aqui me estender sobre o que a Pérsia representa no romance, mas apenas apontar que se, por um lado, ela incorpora características do Império Romano, sobretudo em suas instituições e na relação centralizadora e opressiva com as províncias, por outro, também alude a outras potências imperialistas regionais, como a Pártia ou o Ponto, ameaças à hegemonia romana, de modo que, nessa chave, a campanha de Quéreas pode ser equiparada à de Sula. ${ }^{18}$

A boa relação de Afrodísias com Roma continua após a morte de Sula e ascensão de César (100-44 a.C.) e Otávio (63-14 d.C.), período em que a origem romana em Vênus e Eneias é definitivamente incorporada à ideologia de Estado. Consta que César tenha ofertado a Afrodite de Afrodísias uma estatueta de Eros em ouro, que Otávio intercedeu pessoalmente para recuperar uma vez caída em posse dos efésios. O imperador também declara em cartas ter obrigações para com Afrodísias - de fato a cidade foi liberada do pagamento de impostos em 39 a.C. ${ }^{19}$

Sem sugerir que Cáriton pretendeu escrever um roman à clef, penso que Quéreas e Calírroe opera com inúmeras referências ao contexto histórico amplo, em especial aos que dizem respeito a sua relação com Roma e seus governantes. Assim como a expedição troiana e os poemas homéricos são importantes intertextos do romance, também o são as obras de Tucídides e Xenofonte de Atenas, os discursos de Lísias, Demóstenes, Ésquines e Isócrates, e, não menos, os frisos do Sebasteion e as histórias de poder e conquista que narram, bem como as oferendas guardadas no templo de Afrodite de Afrodísias, deusa prometor dos imperadores, da gente romana e afrodisiense. ${ }^{20}$ São vários os caminhos trilhados pelo narrador de Quéreas $e$ Calírroe, mas com certeza todos eles levam a Roma.

\footnotetext{
${ }^{18}$ Sobre a Pérsia em Quéreas e Calírroe, cf. Baslez (1997); Schwartz (2003); Whitmarsh (2011, p. 56).

${ }^{19}$ Cf. Brody (2001, p. 106-7); Badian (1984, p. 163-5), que citam a carta que Otávio teria escrito.

${ }^{20}$ Sobre a designação que recebe Afrodite em inscrições de Afrodísias, cf. Robert, L. (1966, p. 417, n.1). O autor nota a raridade da designação, contrapartida de propator, mais comum, referindo-se a um deus e/ou ancestral de uma cidade.
} 


\section{REFERÊNCIAS}

APPIAN. Roman History, v. III. Edição de Mendelssohn revisada por Vierecks. Cambridge, Mass.: Harvard University Press, 2002 [1913].

BADIAN, E. Notes on some documents from Aphrodisias concerning Octavian. Greek, Roman, and Byzantine Studies, v. 25, p. 157-70, 1984.

BAKHTIN, M. Formas de tempo e de cronotopo do romance (Ensaios de poética histórica). In: __ Questões de literatura e estética. (A teoria do romance). Tradução de Bernardini, A. F. e outros. São Paulo: Hucitec, 1988, p. 211-62.

BASLEZ, M.-F. De l'histoire au roman: la Perse de Chariton. In: BASLEZ, M.-F.; HOFFMANN, Ph.; TRÉDÉ, M. (ed.). Le monde du roman grec. Paris: Presses de l'École Normale Supérieure, 1992, p. 199-212.

BOWIE, E. The construction of classical past in the ancient Greek novels. In: EKLUND,

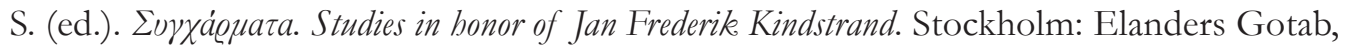
2006, p. 1-20.

BOWIE, E. The chronology of the earlier Greek novels since B. E. Perry: revisions and precisions. Ancient Narrative, v. 2, p. 47-63, 2002.

BRANDÃO, J. L. A invenção do Romance. Brasília: Editora da UnB, 2005.

BRANDÃO, J. L. Qual romance? (Entre antigos e modernos). Eutomia, v. 12, n. 1, p. 80-99, 2014.

BRODY, L. R. The cult of Aphrodite at Aphrodisias in Caria. Kernos, v. 14, p. 93-109, 2001.

CHARITON. De Callirhoe narrationes amatoriae Chariton Aphrodisiensis. Edição de B. P. Reardon. Monacchi: K. G. Saur, 2004.

de CHAISEMARTIN, N. Afrodisia, Roma e i troiani, Omaggio a M. Squarciapino. Archeologia Classica, v. XLIX, p. 29-46, 1997.

CHANIOTIS, A. Vom Erlebnis zum Mythos: Identitätskonstruktionen im Kaiserzeitlichen Aphrodisias. In: SCHWERTHELM, E.; WINTER, E. (ed). Stadt und Stadtentwicklung in Kleinasien. Bonn: Habelt, 2003, p. 69-84.

CONNORS, C. Chariton's Syracuse and its histories of empire. In: PASCHALIS, M.; FRAGOULIDIS, S. (ed.). Space in the Ancient Novel. Ancient Narrative, Supplementum 1. Gronningen: Barkhuis Publishing \& University Library Gronningen, 2002, p. 13-26.

EDWARDS, D. Defining the web of power in Asia Minor: the novelist Chariton and his city Aphrodisias. Journal of the American Academy of Religion, v. 62, n. 3, p. 699-718, 1994.

EWALD, B. C. Resenha de Roland R. R. Smith, The Marble Reliefs from the Julio-Claudian Sebasteion. Aphrodisias, 6. Mainz: Verlag Philipp von Zabern, 2013. Bryn Mawr Classical Review 2014.09.40 (Disponível em: < http://bmcr.brynmawr.edu/2014/2014-09-40.html>. Acesso em: 29 maio 2015.) 
HUNTER, R. History and historicity in the romance of Chariton. In: HAASE, W.; TEMPORINI, H. (ed.). Aufstieg und Niedergang der römischein Welt. Teil II: Principat, v. 34, n. 2. Berlin: Walter de Gruyter, 1994, p. 1055-86.

LAPLACE, M. Les légendes troyennes dans le "Roman" de Chariton Chairéas et Callirhoé. Revue des Études Grecques, v. 93, p. 83-125, 1980.

PERRY, B. The ancient romances: a literary-historical account of their origins. Berkeley; Los Angeles: University of California Press, 1967.

PLUTARQUE. Sylla. In: Vies. Tome VI. Texte établi et traduit par R. Flacelière et Émile Chambry. Paris: Belles Lettres, 1971.

ROBERT, L. Inscriptions d'Aphrodisias. Prèmiere partie. L'Antiquité classique, v. 35, n. 2, p. 377-432, 1966.

SANTANGELO, F. Why 'Sulla Epaphroditos'? In: Sulla, the elites and the empire. Leiden: Brill, 2007, p. 199-213.

SCHWARTZ, S. Rome in the Greek novel? Images and ideas of empire in Chariton's Persia. Arethusa, v. 36, p. 375-94, 2003.

STEPHENS, S. Cultural identity. In: WHITMARSH, T. (ed.). The Greek and Roman Novel. Cambridge: Cambridge University Press, 2008, p. 56-71.

TILG, S. Chariton of Aphrodisias and the invention of the Greek love novel. Oxford: Oxford University Press, 2010.

TRZASKOMA, S. M. Why Miletus? Chariton's choice of setting and Xenophon's Anabasis. Mnemosyne, v. 65, p. 300-7, 2012.

VIRGÍLIO. Eneida. Tradução de Carlos Alberto Nunes. Organização de João Angelo de Oliva Neto. São Paulo: Editora 34, 2014.

WHITMARSH, T. Narrative and identity in the ancient Greek novel. Cambridge: Cambridge University Press, 2011.

Recebido em: 16 de fevereiro de 2016 Aprovado em: 16 de maio de 2016 